\title{
Linear Parks and the Political Ecologies of Permeability: Environmental displacement in SAo Paulo, Brazil
}

DOI:

10.1111/1468-2427.12657

\section{Document Version}

Accepted author manuscript

Link to publication record in Manchester Research Explorer

\section{Citation for published version (APA):}

Millington, N. (2018). Linear Parks and the Political Ecologies of Permeability: Environmental displacement in SAo Paulo, Brazil: Environmental displacement in São Paulo, Brazil. International Journal of Urban and Regional Research, 42(5), 864-881. https://doi.org/10.1111/1468-2427.12657

\section{Published in:}

International Journal of Urban and Regional Research

\section{Citing this paper}

Please note that where the full-text provided on Manchester Research Explorer is the Author Accepted Manuscript or Proof version this may differ from the final Published version. If citing, it is advised that you check and use the publisher's definitive version.

\section{General rights}

Copyright and moral rights for the publications made accessible in the Research Explorer are retained by the authors and/or other copyright owners and it is a condition of accessing publications that users recognise and abide by the legal requirements associated with these rights.

\section{Takedown policy}

If you believe that this document breaches copyright please refer to the University of Manchester's Takedown Procedures [http://man.ac.uk/04Y6Bo] or contact uml.scholarlycommunications@manchester.ac.uk providing relevant details, so we can investigate your claim.

\section{OPEN ACCESS}




\section{ijurr}

\section{Linear Parks and the Political Ecologies of Permeability: Environmental displacement in São Paulo, Brazil}

\begin{tabular}{|c|c|}
\hline Journal: & International Journal of Urban and Regional Research \\
\hline Manuscript ID & IJURR-Art-3695 \\
\hline Manuscript Type: & Article \\
\hline $\begin{array}{l}\text { Please choose one or two } \\
\text { subject categories that best } \\
\text { describe the article's concerns: }\end{array}$ & $\begin{array}{l}1 \text { Property \& spatial processes (including land, real estate, gentrification \& } \\
\text { socio-spatial polarization, housing policy, } 2 \text { Urban movements, social } \\
\text { movements, urban politics, citizenship, underclass \& social exclusion } \\
\text { (political aspects) }\end{array}$ \\
\hline Keywords: & $\begin{array}{l}\text { Infrastructure, Water, Urban Political Ecology, Displacement, Risk, Urban } \\
\text { Geography, Brazil }\end{array}$ \\
\hline $\begin{array}{l}\text { Which world region(s) does the } \\
\text { article focus on? Select up to } \\
\text { five.: }\end{array}$ & $\begin{array}{l}\text { Developing World < World Region, Global South < World Region, } \\
\text { South/Central America \& Caribbean < World Region }\end{array}$ \\
\hline $\begin{array}{l}\text { Which country/countries does } \\
\text { the paper focus on? Select up } \\
\text { to five.: }\end{array}$ & Brazil < South/Central America \& Caribbean $<$ Countries \\
\hline $\begin{array}{l}\text { Which city/cities does the } \\
\text { article focus on? List up to five } \\
\text { cities.: }\end{array}$ & São Paulo \\
\hline
\end{tabular}




\title{
Linear Parks and the Political Ecologies of Permeability: Environmental displacement in São Paulo, Brazil
}

\author{
Nate Millington \\ African Centre for Cities \\ Environmental and Geographical Science Building \\ University of Cape Town \\ Rondebosch, 7701, South Africa \\ nate.millington@uct.ac.za
}

\begin{abstract}
This paper considers the politics of resettlement within ongoing efforts to construct the Tietê River Valley Park [Parque Várzeas do Tietê], a linear park that upon completion will be the largest linear park in the world. Located in the eastern periphery of São Paulo, Brazil, the proposed project uses riverbank naturalization to dampen floodpeaks and bring green space to underserved populations. Yet due to the presence of low-income neighborhoods on the river's edge, the project calls for the removal of roughly 40,000 people. Drawing from Urban Political Ecology and contemporary concerns about environmentally induced displacement, I consider the conflicts over resettlement that mark the project. I analyze the project itself, and situate it within a regional context defined by autoconstruction, regularized flooding, and insecure tenure. I argue that despite claims that the project will yield less risky lives for displaced residents, the form though which the project is being developed actually puts displaced residents in heightened situations of risk. I consider how communities have organized to resist displacement, and call for an approach to governance in peripheral landscapes that takes seriously the histories of collective infrastructural provisioning and autoconstructed housing that have marked them for decades.
\end{abstract}

Key Words: Infrastructure, Water, Brazil, Urban Political Ecology, Displacement, risk 


\section{Linear Parks and the Political Ecologies of Permeability: Environmental displacement in São Paulo, Brazil}

\section{Introduction}

São Paulo, Brazil, is an impermeable city, one traversed by extensive hydrological engineering and intense social inequality. This has produced a landscape that floods, as increasingly severe rain events overlap with extensive development to produce an urban pattern that gives little space to water's circulation. Due to long-standing patterns of inequality and residential segregation, flooding disproportionately affects low-income communities, many of which are located in floodplains and on the edge of the city's rivers and reservoirs. There is a direct relationship between the city's waterways and broader patterns of environmental (in)justice. Flooding and water management are intimately connected to broader dynamics of residential inequality and informal housing, meaning that the management of stormwater takes on distinctly political forms.

This paper considers one attempt at managing flooding in São Paulo: the Tietê River Valley Park [Parque Várzeas do Tietê] (hereafter PVT), a linear park currently being constructed by the state government in the city's eastern periphery. While São Paulo’s stormwater management has long been reflective of large-scale, so-called "promethean" approaches to infrastructural provisioning, the city and state have tentatively embraced the development of linear parks as a means of improving water quality and easing the impact of flooding in the last two decades (Jacobi, Fracalanza \& Silva-Sánchez, 2015; Soares, 2014; On “promethean" infrastructure, see Kaika, 2005). Working against the long-standing principle of "rapid transit" in stormwater management, which attempts to funnel stormwater out of urban areas as fast as possible, these green spaces are instead designed to retain stormwater and slow its path. Sometimes associated with the turn towards green infrastructure, linear 
parks are suggestive of changing paradigms of stormwater management worldwide that stress the capacity of the natural landscape to retain and delay the movement of rainwater.

While the majority of linear parks in the city are small-scale interventions into the landscape, the PVT is on an entirely different scale. Ultimately designed to bridge a series of municipalities, it will be the largest linear park in the world upon completion, stretching for roughly 75 kilometers to the source of the Tietê River near the town of Salesópolis.

Designed to dampen flood peaks that have been heightened by extensive development in the region, the PVT proposes the renaturalization of the Tietê's banks in the eastern edge of the city. Yet due to the presence of low-income communities along the Tietê in a region commonly referred to as the várzea [floodplain] $]^{1}$ (see figure 1), the project calls for extensive population displacements. Specifically, the PVT calls for the removal of 8,000 families [roughly 40,000 people] to return the Tietê's banks to their historic function as flood regulators (Governo do Estado de São Paulo, 2010). As with other linear park projects in the city, the PVT has become a flashpoint in conflicts between housing movements and the state (Observatório de remoções, 2012).

This paper considers the PVT's plans for removals in light of ongoing work in geography and urban political ecology on the relationship between environmental interventions and processes of displacement (See, for instance, Banzhaf and Walsh, 2006; Checker, 2011; Dooling, 2009; Doshi, 2013; Ghertner, 2015; Patrick, 2014; Wachsmuth, Cohen, \& Angelo, 2016). Engaging with the specificities of the PVT allows for a consideration of the processes through which removals are both legally articulated as well as carried out. My assessment of the PVT subsequently draws both from broader political-

\footnotetext{
1 The Portuguese word várzea translates to lowland or plane. For Aziz Ab'Saber, the usage of the word in the southeast of Brazil refers to the flat lowlands along the edges of fluvial channels. For the purpose of consistency, I either leave the word in its original Portuguese or translate it as floodplain.
} 
economic understandings of the city's urban dynamics as well as the environmental logics that are used to justify the project. What is happening in São Paulo around the PVT is a clear case of environment-induced displacement. Yet in contrast to a normative argument that all retreat from environmentally fragile areas is a form of dispossession, I show how displacement in this case becomes specifically risky for low-income residents living in precarious situations (See Koslov, 2016, on retreat and displacement). This is not a product of removals as such but rather the specific forms through which removals are being conducted.

The organization of this paper is as follows. First, I consider the dynamics of displacement that mark the project, and critically analyze the discourse around risk that underlies ongoing efforts to remove populations in the region. I focus on risk due to the fact that it is one of the foundational forms through which environmental improvements are justified in São Paulo and beyond (See, e.g. Zeiderman, 2016). I take issue with the claim that removal in its current form will render residents' lives less risky, and argue that São Paulo’s state government has operated without transparency in developing the project. Second, I discuss how communities have responded to the threat of evictions, and focus on moments of small-scale political mobilization against removal. I note that the cost and complication of removals gives opening for social movements interested in stopping, or at least stalling, removals. I conclude the paper by calling for an approach to governance in peripheral landscapes that takes seriously the histories of collective infrastructural provisioning and autoconstructed housing that have marked these landscapes for decades.

\section{The Political Ecology of Housing in São Paulo}

São Paulo is a city of roughly twenty million people, marked by an enduring disconnect between a broadly formalized urban core and an increasingly heterogeneous periphery (See 
Caldeira, 2001; Rolnik, 2015). Throughout the twentieth century, the city underwent an expansive process of peripheralization that was marked by the persistent settlement of lowincome communities at the city's edge (Caldeira, 2001, 2016; Holston, 1991, 2008; Keck, 2002; Kovarick, 2009; Rolnik, 1997). Coupled with the related processes of autoconstruction and occupation, in which residents slowly built homes and communities by hand, the result was that São Paulo expanded dramatically throughout the twentieth century but primarily in its peripheries. Over time, expansion would yield formalization and consolidation, resulting in a patchwork peripheral landscape that threads between the informal and the formal, where poverty coexists with decades of economic growth and neighborhood consolidation.

São Paulo’s bifurcated landscape of center and periphery is directly connected to its waterways (see, for instance, de Sant'Anna, 2007; Jacobi, Fracalanza \& Silva-Sánchez, 2015; Jorge, 2006; Seabra, 1987; Silva, 2012). While the locating of low-income neighborhoods in floodplains has marked the city since its inception (See Jorge, 2006), central city expulsion furthered this process. Low-income residents were pushed to settle in parts of the city that existed outside of the housing market, including areas at risk of flooding or landslides, public lands, and green spaces. The occupation of riverbanks and other floodprone landscapes is subsequently a constant process in the city, yielding an intimate relationship between inequality, flooding, and formal illegality. This has implications for environmental management, especially in regards to water quality. The locating of favelas and other forms of semi-formal urban typologies in floodplains and on riverbanks can complicate efforts to implant sanitary infrastructure, and often forces low-income residents to trade stable housing for frequent flooding (See Barboza, 2015).

Housing remains a vital area of political struggle in São Paulo (See Boulos, 2014; Cohen, 2016, 2017; Rolnik, 2015). Current estimates place São Paulo’s housing deficit at 230,000 
units, a figure that ignores the precariousness that marks much of the city's housing more generally. In São Paulo, this is especially noticeable given the high rates of vacancy in the urban core, where hundreds of thousands of habitable apartments remain tied up in real estate speculation and vacancy. 2010 census figures indicated that roughly $10 \%$ of São Paulo's population lives in favelas and other irregular settlements, up from less than $6 \%$ in 1991 (See Marques, 2014; Pasternak and D’Ottaviano, 2016).

\section{Methods and Conceptual Framing}

The entangling of water and inequality that makes up São Paulo's landscape requires an approach that is attentive to the complex, overlapping dynamics of governance that materialize in the city. This paper draws extensively from urban political ecology (UPE) in order to consider how the benefits and burdens of the city's watery landscape are mediated by broader political and social dynamics in the city (See, for instance, Bakker, 2010; Gabriel, 2014; Heynen, 2013; Rademacher, 2011; Ranganathan, 2014; Swyngedouw and Heynen, 2003; Swyngedouw, 2004). An approach drawn from UPE highlights the differentiated results of environmental interventions into cities, and considers the forms through which urban ecologies are mediated along lines of race, class, gender, and geography. I further draw from the insights found in the literature on environment-induced displacement, which has considered the processes through which environmental initiatives around sustainability have led to displacement of lower-income populations throughout the global North and South (See, e.g. Banzhaf and Walsh, 2006; Checker, 2011; Dooling, 2009; Doshi, 2013; Ghertner, 2015; Patrick, 2014; Zeiderman, 2016). While much of this literature has considered environmental interventions in urban contexts marked by gentrification, this paper expands on this literature through an analysis of displacement within a southern city defined by histories of autoconstruction, inconsistent land tenure, and peripheral urbanization processes 
(See Caldeira, 2016). Finally, this project engages with the broad work in the politics of infrastructure (See, e.g. Anand, 2017; Barnes, 2016; Caldeira, 2016; Carse, 2012; Furlong, 2014; Graham and Marvin, 2011; Holston, 2008; Roy, 2005, 2009; Silver, 2014; Truelove, 2011) through a consideration of how the urban socio-natural landscape is held together through processes of maintenance and repair that cut across binaries of water and land (Barnes, 2016; Graham \& Thrift, 2007; Mandelman, 2015; Mathur and da Cunha, 2014; Thrift, 2005). In doing so, the paper engages with the nature of contemporary governance in São Paulo and calls for further attention into what Angel and Loftus (2017) provocatively refer to as the "the set of socio-ecological relations that goes by the name of the state" (See too Angel, 2017; Harris, 2017).

Research for this paper was conducted over the course of 22 months between 2013 and 2016. In order to get a holistic sense of the park's development and insertion in a specific region, I interacted with a wide range of actors involved with water, infrastructure, and activism throughout the city. I conducted roughly 45 semi-structured interviews with water professionals, state representatives, and neighborhood activists throughout São Paulo. These were complemented by a variety of informal conversations, walking tours, observation of meetings, and discourse analysis of texts and representations that dealt with water and peripheral urbanization dynamics. Additionally, I participated in meetings of a variety of small-scale social movements active in the várzea, including the Floodplain Committee [Comitê da Várzea], Communicators of the Floodplain [Comunicadores da Várzea], Organized Cultural Action Afro East [Ação Cultural Afro Leste Organizada Afro-Leste], Movement for the Urbanization and Legalization of Pantanal [Movimento por Urbanização e Legalização do Pantanal], and the Movement for the End of Floods Itaim Paulista [Movimento pela fim das enchentes Itaim Paulista]. While I participated in events 
throughout the city, I focused on the sub prefectures of São Miguel Paulista and Itaim Paulista. These sub prefectures were selected due to their proximity to the Tietê River, their recurrent problems with flooding, and their connection to broadly peripheral processes of urbanization. At the state level, I met with representatives of the Department of Water and Electrical Energy (DAEE), the São Paulo Housing and Urban Development Company, and the environmental secretaries at both the state and municipal level.

The civil society representatives and activists profiled in this text are largely affiliated with small-scale social movement and neighborhood associations. Some of these organizations are linked to local religious organizing yet the bulk are not. While many activists had party affiliations (often with the Worker's Party [PT] and the Party of Socialism and Liberty [PSOL], as well as the Brazilian Democratic Movement Party [PMDB]), the activists that I spoke with largely articulated their projects in terms of neighborhood-level organizing and often referred to themselves through the term community leader [lider comunitário]. While present in the political life of peripheral communities, it is important to note that outside of mass movements like the Movement of Homeless Workers [MTST], peripheral social movements lack the visibility they had in the 1980s and 1990s. In lieu of mass mobilization, much of the political activity in the urban periphery often takes place in the courts. Specifically, appeals are regularly made to the Public Ministry, an independent branch of government that allows for citizens to bring class action lawsuits against the state and the private sector (See Coslovsky, 2015; Holston, 2008; See also Bhan, 2016, on the “juridicalisation of resistance”). While the 2014-2016 period in Brazil was marked by extensive mobilizations that brought many residents to the street, much of the political life that I witnessed in the periphery of São Paulo took the form of bureaucratic contestation, appeals to the public ministry, and engagement with local decision makers. These 
approaches were occasionally complemented by more visible politics of occupation and direct action (See Barboza, 2015).

Water governance in São Paulo involves a series of overlapping jurisdictions and authorities whose ambits are not always clear (See, e.g. Abers and Keck, 2014; Keck, 2002; Porto, 2012; Silva, 2012). Based on the three principles of decentralization, integration, and participation, the Tietê River falls under the administrative control of the Upper Tietê watershed committee, which is comprised of 36 municipalities and 48 members (drawn equally from state, municipal, and civil society sectors). The PVT itself falls under the institutional mandate of the Department of Water and Electrical Energy [DAEE], who are responsible for the construction of the project as well as the coordination of removals. The actual removals themselves are the responsibility of the state housing secretary, as well as the municipal housing authorities for the cities of São Paulo and Guarulhos. Environmental licensing is provided by the Environmental Company of the State of São Paulo, and underlying zoning is largely governed by the management plan for the Tietê Area of Environmental Protection, which is itself governed by the state environmental secretary.

\section{Situating The Parque Várzeas do Tietê}

The PVT proposes an extensive green space that will preserve the riverbanks of the Tietê in eastern São Paulo and bring green space to underserved populations. As the Department of Water and Electrical Energy notes on the project's website:

The principal objective of the program is to recuperate and protect the function of the river's várzeas, in addition to functioning as a regulator of floods, saving lives and people's property. At the same time, the Tietê Floodplain Park proposes a gigantic leisure area for the population (Departamento de Águas e Energia Elétrica, 2015).

The PVT is the exception to the generally small-scale, underfunded linear parks that mark riverbank green space initiatives in São Paulo (See Jacobi et al, 2015; Soares, 2014). It boasts a much more robust budget than other park projects, with a budget of over 500 million 
dollars and financing from the Inter-American Development Bank (Departamento de Águas e Energia Elétrica, 2015). Upon completion, the park will stretch for 75 kilometers, creating a green corridor that extends far out of São Paulo (See Figure 2). It has been marketed as the "largest linear park in the world," even as it remains a project with very little public presence.

Divided into three stages, the PVT's first phase of development is slated for the eastern edge of São Paulo on the banks of the Tietê. This is a region colloquially referred to as the várzea [floodplain], a complex region that combines decades of consolidated, autoconstructed settlement with inconsistent dynamics of land tenure. ${ }^{2}$ The portions of the várzea that will be affected by the first stage of the PVT's development are low-income neighborhoods at the edge of the city, prone to recurrent flooding. While flooding is fairly regularized in São Paulo, its intensity shifts by the year. In the summer of 2009/2010, floodwaters dramatically inundated peripheral neighborhoods located in the floodplain of the Tietê. In communities like Jardim Pantanal, a long-standing occupation located on the banks of the river, the waters remained in the region for nearly two months (See Barboza, 2015). As Marta, the manager [gestora] of the PVT noted in a 2014 interview, flooding in 2009 was the:

...worst flood that we have confronted here. What happened? Look, the river filled up... and it had nowhere to spread its water. It spread into the houses, or the houses occupied where it needed to spread. And so this project here, it creates a physical barrier, which is a park lane, a bike lane, to secure, to maintain the distance from the river (emphasis mine).

The PVT attempts to reorient the complex fluvial landscape of the várzea in the service of flood prevention and environmental remediation, to develop a more permanent solution to flood management in the region. The project proposes the construction of a series of

\footnotetext{
${ }^{2}$ For the purposes of this paper, the várzea as a region of São Paulo extends east from the Penha Dam to the border between São Paulo and the municipality of Itaquaquecetuba. Within São Paulo, it includes portions of the sub prefectures of Penha, Cangaíba, Ermelino Matarazzo, Vila Jacuí, São Miguel, and Jardim Helena.
} 
leisure centers or parks, linked together by an extensive bike lane and green space that will allow the river to flood while also impeding informal and irregular occupation in the region (See Figure 3). The PVT's proposed green spaces include 33 leisure centers [nucleos de lazer], a $230 \mathrm{~km}$ bike lane, 77 soccer fields, and $75 \mathrm{~km}$ of uninterrupted green space in total. This scale makes clear that while previous linear parks in São Paulo have been largely piecemeal, the PVT is on an entirely different scale. It is a massive rearticulation of the relationship between river and city in São Paulo, one that will reconfigure both the informal urbanisms of the várzea as well as the agricultural landscapes that mark the city's eastern hinterlands.

The PVT is in line with ongoing shifts in the management of stormwater infrastructure. In recent decades, hydrological engineers have attempted to reduce the cumulative water that flows through São Paulo through the use of detention ponds and occasional riverbank naturalization (See Canholi, 2005; Júnior, 2011). In doing so, engineers have overseen a shift in flood prevention that peripheralizes infrastructure and scales up the field of intervention. A product of scientific knowledge as well as budgetary constraints and land pricing, this is one form of how flood management in the city is often inserted into broader dynamics of center and periphery that mark the city. Peripheral communities regularly allege that flood prevention policies use the urban periphery as a type of sacrifice zone for the broader city through the placement of detention ponds [piscinões], even as they call for sustained investment into the recurrent problem of flooding.

The PVT continues this logic: It is specifically designed to clear the riverbanks in the eastern periphery of the city in order to reduce the effects of flooding downstream. Its specific purpose is to expand the absorptive capacity of the river channel and dampen flood peaks, whose dynamics have shifted given the intensity of occupation in the region and the 
issues of impermeability that have accompanied those processes. The Management Plan for the Tietê Floodplain Area of Environmental Protection [Plano de Manejo: Area de Proteção Ambiental, Várzea do Rio Tietê], for instance, notes that the velocity of flood peaks has increased dramatically in the last three decades due to the lowering of the absorptive capacity of the landscape. This is occurring at the same time that the further deepening of the Tietê's channel is allegedly no longer physically possible, meaning that the only way to prevent flooding in the urban core is to remake the landscape of the várzea on a massive scale.

\section{Riskiness and Removal}

The PVT calls for the removal of 8,000 families (roughly 40,000 people). These removals are largely justified as a way to reduce flooding and take residents out of risk. DAEE and the state government argue that informal settlements in environmentally fragile areas provoke erosive processes and alter flood regimes, while also subjecting residents to flooding and waterborne diseases. Flood prevention is subsequently the primary justification for popular resettlement, but the PVT also stresses the benefits of resettlement in state-built housing complexes. As Marta, the manager of the project, noted in response to a question about the benefits of removals:

Because who leaves will have housing with resources. It might be smaller, but you're [not] on the edge of the river. It has sewage, it has internet, light, everything. And who stays has a park in front of them. And those who leave also have a park they can visit (Marta, personal interview, 2014).

Removals in this sense are not just ecologically necessary but seen to benefit communities with unclear land tenure and proximity to environmental risk. In the resettlement plan for the PVT, for instance, the authors write:

There is inadequate sewage collection, trash collection and water provisioning, factors of environmental degradation that turn the areas unhealthy and expose the population to sanitary risks. This situation is most critical in the flood season when thousands of residences are invaded by water that is often polluted and carries disease vectors (Governo do Estado de São Paulo, 2010: 13). 
In these framings, DAEE reflects changing articulations of favela removals throughout São Paulo that stress the benefits of resettlement for affected populations.

While in agreement about the riskiness of living in the Tietê's floodplain, I argue that discourses of risk that are used to justify popular removal are inconsistent given the forms through which resettlement is being carried out in the region. I argue that the removal of precarious communities in the várzea will produce risker lives for residents due to the lack of transparency in the process and the inability to take seriously residents' immediate and longterm needs. This argument takes on special relevancy given the fact that risk reduction and an improved standard of living borne from resettlement are some of the primary ways in which removals of low-income communities are justified in São Paulo (and beyond). Risk is both an important ethical as well as practical dimension within contemporary slum governance in the city, serving as one of the primary means through which removals receive financing. Specifically, if communities are declared at risk, it gives residents access to specific funding sources that allegedly cover the costs of resettlement. This subsidy_social rent [aluguel social] — is designed to cover living expenses while state-built housing is under construction. Due to construction delays and general bureaucratic slowness, these subsidies often become semi-permanent.

The dynamics of riskiness are evident in the removals that have already taken place as part of the development of the PVT. In the wake of the 2009 and 2010 flooding in the várzea, 2,661 families were bought out by the state. The lack of legal tenure for most residents meant that the majority received a monthly housing subsidy of $300 \mathrm{R} \$$ (currently \$95) and the promise of resettlement in a state housing complex (See Barboza, 2015). The majority are still awaiting the promised housing. This is a point verified by residents but also by DAEE themselves, who noted in a 2015 progress report on the project's implementation: 
Of the 7,115 families [determined to require removal], 2,661 families were removed due to the floods in the summer of 2009/2010, with 240 being sent to buildings built by the São Paulo Housing and Urban Development Company [CDHU] (in 2010), 203 to buildings under the responsibility of the secretary of habitation [SEHAB] (in 2012 and 2013) and 2,118 continuing to receive housing support, whose costs are divided equally between the State Government of São Paulo / Secretary of Habitation - CDHU and the Mayor's office/SEHAB (UGP Várzeas, 2015: 106).

This means that of the 2,661 families removed from their homes in 2009 and 2010, only around 450 were actually given the housing promised.

This has produced a situation in which many previously removed residents have returned to the area (See Figure 4). As activist Anderson of Itaim Paulista noted in a 2014 interview:

Look what the government does. They take you out of risk and put you in worse risk. Because this is what happens. They are going to take these people and put them in an apartment that is far, far, far away. These people will sell for 20 thousand [reais, approximately \$6283.08]. Twenty thousand lets you buy what? And so they'll buy a shack in the river. And will they have a right [to be resettled] again? No, because they're already registered.

Even successfully completed removals can be fraught due to the dynamics of delay and illdefined housing policy. The construction of public housing complexes in Brazil is notoriously low quality (See, for instance, Rolnik, 2015). Indeed, in an investigative reporting detailing the removals of communities in the várzea in the wake of 2009 and 2010 flooding, Pacheco (2012) found that many residents were dissatisfied with the housing units that had been built. More broadly, the locations of these projects are often far from the urban core, increasing travel times and further marginalizing peripheral residents into distant locations. Relocation can often lead to deeper questions of security and safety for displaced residents. Furthermore, removals and the associated delays can often cause banal issues that have profound effects, such as questions of where to store possessions during periods of movement. For low-income residents, these sorts of seemingly minor delays can add up in profound ways. Related is the degree to which rent subsidies generate their own forms of expulsion. In lieu of actual housing, the distribution of rent subsidies in the várzea had the 
perverse effect of encouraging speculation and raising local rents. As local activist Marzeni noted in a 2016 interview, this was especially pronounced in places like Jardim Pantanal as nearby residents knew about the continued subsidies and would subsequently attempt to charge displaced residents more.

In spite of all these dynamics, many residents of the várzea that I spoke with in 2014 and 2015 were not opposed to removals in all cases. To say that all low-income residents in São Paulo would prefer to stay put ignores the heterogeneity of peripheral communities and the broader degree to which many housing movements are actively engaging with the state. But many residents and activists were and are opposed to removals that are conducted piecemeal and without an adequate plan. As activist Vagner put it in 2014, residents wanted a process that was "more humane." This was a point made repeatedly by activists in reference to the proposed construction of the PVT. Scholars of peripheral urbanization often highlight the cases of resistance against state projects in the form of dramatic refusals to leave (See, for instance, Perry, 2013). However, what I witnessed in the várzea throughout my research were more conciliatory positionings borne out of long histories of marginalization and insertion into local political networks.

Conflicts over removals are often provoked by the details and the lack of consistent follow through on behalf of the state, rather than the threat of removal as such. While many residents were clear that they did not intend to be moved, others understood the dynamics of risk and resettlement and understood that they were living in areas of environmental protection that exposed them to danger. Following Ghertner's (2015) framing of slumdwellers' embodied understandings of themselves as out of place, we might say that some peripheral residents of São Paulo had come to find environmental arguments convincing and became convinced of their insuitability to live in the Tietê's floodplain. As a 
result, many residents grew excited about the possibilities of subsidized housing and the chance to move out of the region. Activists rarely articulated politics of wholesale resistance to resettlement in state housing projects. Instead, they asked repeatedly for timeframes, for information, for details on the projects, and for conversation. These requests were rarely met.

Instead, throughout 2014 and 2015, I witnessed a definitive lack of transparency on behalf of DAEE This was in spite of the fact that employees of DAEE understood the effects of these projects and the logistical as well as ethical difficulties of removing populations. As Celso, a DAEE employee, noted when discussing the proposed removals of nearly 5,000 families in the municipality of Guarulhos: "It'll be a little delayed, and maybe it won't even be us that does it. And part of it we might not even be able to do." When I asked further, he noted:

[It's] difficult, complicated...It will be very expensive, it will be traumatic, and it won't be an easy job to do in one phase. Maybe the project will have to be restudied, reformulated, replanned or suddenly the possibility of some financing from the government will appear and we'll be able to do it one pass... So: do it and finish it, or do it and keep having to redo it because occupation is constant. You pass by today and there is no shack and tomorrow there is one.

Given the nature of state fragmentation in São Paulo, collaboration between housing and environmental secretaries is often conflictual. This produces a situation in which housing is seen as a secondary concern, one that is out-sourced to specific entities. The result is a lack of coherency within projects that has serious implications for communities slated for removal.

This is a point made by the limited academic work on the development of the PVT. Pereira (2012:6), for instance, notes that:

In spite of the affirmation that areas for relocation are still to be identified, in the actual stages of the project they are precisely defined. But we do not have mention of the effective initiation of the projects nor of the communication to the hundreds of families 
that will be removed. In all the forums that we participated in, including the offices and meetings with sectors of civil society, the central complaint was not just the fact of removal, but how, when, and where the relocation would occur.

I witnessed these moments too in my own research practice. On October 18, 2014, I took a walking tour in Jardim Pantantal, organized by the Communicators of the Várzea [Comunicadores dá Varzea] and Free Earth [Terra Livre], two social movements with representatives in the region. Our purpose of the walk was to chart the purported line that demarcated eventual removals in the region, part of a broader solidarity-building effort on behalf of the resident-activists. As we walked, we used two maps, one that the local activists were using and another that was in the hands of some students at the university of São Paulo. At one point, we reached a moment where the maps diverged (figure 5), where one showed a line going straight, and one veered, performing a detour before eventually meeting back up with the line that we were on. This suggested that an alteration had been made to the original plan, that determinations of who would be removed were still being decided, and that residents were not being given adequate information. Given that this line determines who will be forced to leave a long-standing community, this lack of clarity had and has potentially very real consequences for specific people.

This moment of cartographic anxiety was suggestive of the broader lack of transparency in the implementation of the PVT, a sticking point that consistently circulated in the communities of the várzea during 2014 and 2015. The sense that the state knew what they were doing permeated discussions, even as the state's own practice seemed to suggest otherwise. If risk is one of the defining discourses through which this project is being articulated, a lack of transparency in its implementation makes clear that its development will produce riskier lives for displaced residents. Without a transparent policy of engagement that takes seriously the multilayered dynamics of risk that accompany resettlement, projects like 
the PVT will yield risker situations for residents unless plans are made to avoid construction delays, to safeguard possessions, and to develop coherent housing plans that understand residents' needs and desires in real ways. The PVT makes clear that even if some number of removals can be justified through hydrological logics, the form through which residents have been treated is cause for serious concern.

\section{Democratizing the várzea and the governance of relational landscapes}

In response to ongoing processes of displacement, the várzea has witnessed periodic moments of resistance to removal organized by local social movements. In response to the flooding in 2009 and 2010, for instance, activists responded forcefully, leading extensive protests and even developing an occupation of those displaced by the floods. Detailed by Barboza (2015), activists (largely affiliated with MULP, or the Movement for Legalization and Urbanization of Pantanal) protested by blocking streets and setting fire to furniture ruined by floodwaters. Residents traveled to the urban center to stage protests at the mayor's office calling for the uninterrupted opening of the dam's floodgates, for an equitable housing policy, and for the immediate dredging of the Tietê River (Barboza, 2015: 40). In April of 2010, nearly 100 families occupied a piece of land under the banner of "Occupation - The flooded ones of Pantanal" [Ocupação - Alagados do Pantanal]. The occupation lasted for 34 days, but was ultimately removed.

In September 2014, I met with a group of 13 residents (and their children) from the neighborhoods of Jardim Helena and Jardim Aymoré, largely cohered under the banner of the Movement for the End of Floods Itaim Paulista. Organized by local activist Anderson, it was immediately clear that these residents-largely precarious, often in situations of serious risk — did not want the promised apartments, understood that they were too poor for even subsidized housing, and were not excited about the thought of a park. Two strategies were 
discussed for going forward: the development of a media campaign dedicated to highlighting both flooding and evictions, and appeals to the public ministry. In a meeting two months later, Anderson demonstrated this approach by engaging in some political theater, calling the scheduler for the mayor's office on speakerphone to demand a meeting. He was politely informed that schedule requests are typically done over email.

These moments of small-scale direct action are representative of much of the current shape of peripheral political mobilization in São Paulo that I was witness to throughout 2014 and 2015, the sorts of everyday politics that exist alongside more visible manifestations. They are not representative of mass mobilizations against evictions, but rather smaller mobilizations in the context of uncertain possibilities. While evaluating their success remains to be seen, it was clear from engagements with employees of DAEE that pressure was having some effect as employees repeatedly expressed fatigue with local pastors and activists. In a meeting with regional representatives in September 2016, for instance, Marta, the manager of the PVT, noted that removals deemed necessary for the development of a polder in Vila Itaim had been lowered to 129 families from 394 due to pressure from both activists as well as concerns from the municipal secretary of housing (Jornal da Várzea, 2016).

The cost and complication of resettlement creates an opening for social movements. Indeed, resettlement is often cited as the primary cost of engineering projects in São Paulo (See, e.g. Sagamarchi, 2013). Taking advantage of the state's fiscal limitations and the legal specificities of the Brazilian constitution, social movements and activists in the periphery have been able to temporarily block projects and downplay their potentially negative effects, primarily through appeals to the courts (in particular, the public ministry). This results in a situation where removal becomes even more fiscally complex. These logistical complications have allowed for peripheral communities to remain in place quasi-indefinitely, yet often in 
conditions of what Yiftachel (2009) refers to as "permanent temporariness" given their lack of formal land tenure. At an April 2017 Cornell University workshop discussing the construction of detention ponds [piscinões] in São Paulo, for instance, a representative of one of São Paulo's primary water NGOs noted that attempting to remove a favela of roughly 500 people was impossible and should not even be considered. This was not an ethical consideration but rather a pragmatic one.

Temporary slowdown amidst continued exposure to environmental risk is not a longterm strategy for resisting displacement or securing dignified housing. But it demonstrates the types of strategic politics that keep people in homes while the structural dynamics of inequality remain unchanged. In the remainder of this paper, then, I am interested in thinking through what a state practice that attempts to balance dispossession with environmental improvement could look like in landscapes of austerity where fiscalização [management] is often inconsistent (what Nobre, Martin, and Lima (2015) refer to as "the difficulty of being simple in complex landscapes"). I draw inspiration from the processes of autoconstruction and collective infrastructural provisioning that have marked peripheral landscapes of São Paulo and beyond for decades (See Bhan, 2016; Caldeira, 2016; Holston, 2008; Lawhon and Makina, forthcoming; Makhulu, 2015; Vasudevan, 2014; Von Schnitzler, 2016; On collective infrastructures, see Amin, 2014). Often associated with urbanization in the global south, autoconstruction [autoconstrução] emerged from the historical entanglement of inequality, differentiated citizenship, and uneven access to land that marks urbanization patterns in Brazil. It is a process in which residents slowly build homes, primarily by hand and primarily on days off from work. Linked to the related process of collective infrastructural provisioning —what Amin (2014) calls "lively infrastructure"autoconstruction is a form of urban appropriation that makes demands on the state for 
dignified housing and a right to the city. By no means independent of state involvement, autoconstruction is instead a reaction to state neglect that makes claims on the state itself.

While being clear that autoconstruction emerges from inequality and limited options, I take inspiration from autoconstruction for thinking through approaches to environmental improvement in landscapes like the várzea for two reasons: First, it demonstrates a processual approach to landscape creation and a skepticism of large-scale planning in favor of what Pieterse (2013) calls “radical incrementalism;” And, second, it articulates an approach to the urban fabric that is, at heart, about appropriation, prioritizing the right to dignified housing. To what extent these features can be incorporated into state projects could determine what sorts of possibilities exist for balancing social and ecological dynamics in landscapes like the várzea. Autoconstruction and peripheral expansion will remain central components of São Paulo’s landscape as long as the city's formal housing shortage remains unchallenged. And despite recent glimmers (See, e.g. Pardue, 2015), ongoing pushes towards austerity at both the federal and local level mean that it is unlikely that broad changes to the city's urban pattern will occur in the years to come. Indeed, the recent election of Joao Doria as mayor of the city makes clear that a progressive, pro-poor housing policy will not be a priority in the years to come. As such, engaging with landscapes like the várzea requires taking seriously the improvisational forms through which landscapes are produced, and asking how those might be folded into specific responses to flooding and environmental risk governance.

Osvaldo, a long-standing activist in the várzea, gives voice to this:

I think the government has to create more serious policies, you know? They have to actually think about the local community, the environment of that community. And there are mechanisms for that. Its not impossible to do... The people can stay, you can, instead of planting, instead of cementing the yards: grass, ecological sidewalks, ecological pavement, everything sustainable, a project of environmental education, create a partnership with the university of São Paulo, create the incubator, hire people who live in 
the community...there is so much you can do, you know? And it would be an example for society, for Brazil, for the world, and the government prefers... And so, sometimes, I don't understand these things, you know? I don't get it. You have things that can change lives, right? (personal interview, 2014)

These suggestions are ways forward for an approach to flood prevention that situates infrastructure within the political and social dynamics that mark the periphery. Infrastructure here is understood in both social and technical terms, and the management of water is incorporated into the everyday practices of collective construction that marked the development of neighborhoods in the várzea. Infrastructure, here, is folded into the landscape itself.

At the broader state level, one can point to projects like Pantanal Project [Projeto Pantanal], a broad favela upgrading program that involved long processes of relationship building in a neighborhood within the Tietê's floodplain. While removals formed a component of the project, the construction of housing complexes in the region meant that residents were largely given housing in their pre-existing neighborhood. One can point as well to the Management plan for the Várzea of the Tietê, produced by the environmental secretary. That plan, developed in consultation with geographers and cartographers affiliated with the University of São Paulo, legalizes most existing occupation in an attempt to preserve the remaining landscape through graduated zoning. Both projects involved extensive involvement with and from local communities, even as they are by no means perfect projects. Both push back against large-scale plans of landscape remaking in favor of situating flood prevention within the broader political ecology of housing in the region.

In this, these project echo contemporary work in design that has called fluvial accommodation in deltaic landscapes (See, for instance, Milligan, 2015, Mathur and da Cunha, 2014). Mathur and da Cunha (2012), for instance, call for an expansive, horizontal engagement with water as intimately enmeshed with terrestrial landscapes (2012: 3). When 
considered in the specific context of the várzea, Mathur and da Cunha's work subsequently offers a provocation to consider what design practices rooted in the understanding of water's constant presence could offer for balancing flood prevention infrastructure and semiconsolidated housing. Work on flood adaptation in New Orleans in the wake of Hurricane Katrina highlights the possibilities and dangers of this work, juxtaposing the often compelling possibilities afforded by design with the realities of racialized poverty, inequality, and limited financing (See, e.g. Mandelman, 2015; Meyer, Dale, and Waggoner, 2009).

All of these projects suggest tentative possibilities for balancing habitation with environmental improvement in the landscapes of the várzea, yet all are complicated by the static imaginaries of the landscape that underlie projects like the PVT. By focusing on processes of autoconstruction in the várzea, I am not interested in romanticizing the brutal inequalities that yielded autoconstruction. Nor am I suggesting that flood prevention infrastructure should be built haphazardly and by hand. Rather, I argue that environmental improvements in landscapes marked by tenure insecurity should prioritize interventions at a variety of scales, should focus on the management of already existing infrastructures, and that dignified housing should be seen as the first step in any project. Autoconstruction here functions both as material politics but also as a broader metaphor for urban governance, carrying overlaps with existing work on the development of "heterogeneous infrastructural configurations" in cities of the global south (See Lawhon et al, 2017; See also Amin, 2014; Furlong, 2014). Throughout my research in the várzea, what residents seemed to want most were not parks or new promises, but rather consistency and follow through on plans previously made. Without a sustained commitment to the region's residents that takes seriously their rights to stay and the histories of the landscapes they inhabit, projects like the PVT will only hurt residents. 


\section{Conclusion}

Nearly ten years in, the PVT has little to show for it beyond a series of designs, an 11 kilometer bike lane, and one completed park space that is only nominally connected to the project. The three primary núcleos for the project that have been planned-Itaim Biacica, Vila Any, and Jardim Helena_-are all in development, with Itaim Biacica being the only one to show evidence of construction as of December 2016. While project employees made clear to me that the project was progressing, fiscal and political crises in Brazil suggest that the project may remain unrealized in the years to come. In addition to the broader logistical and financial costs of resettling populations deemed at risk, the underlying dynamics of land ownership complicate project plans. The lack of a consistent and transparent policy process in the várzea has generated a project that is delayed and possibly at risk of failure. As the project stalls, the várzea floods. In March 2016 as well as January 2017, flooding returned dramatically to the communities of the region, damaging property and livelihoods again. Water surged out of the local streams that crisscross the region and out of the stormsewers, provoking property damage and losses more broadly. The continued reality of flooding in the region is a dramatic indictment of the PVT's stalled ambitions and one more example of an approach to water management in Brazil that has reached its limit.

In this paper, I considered the case of the PVT in light of broader concerns about the link between environmental improvement and displacement. I considered the lack of transparency in the implementation of the PVT, and critiqued the broader idea that its development will yield less risky lives for affected communities. I argued that the project threatens to put low-income residents into situations of heightened rather than lessened risk and critiqued what I saw as a lack of transparency in the implementation of the project. I discussed moments of resistance to removal and further argued that models for how to 
delink displacement from environmental improvement could find inspiration from existing processes of autoconstruction. I argued that autoconstruction was both a form of material politics as well as a metaphor for a different kind of state practice, one that takes seriously the fiscal and institutional limits in places that have long existed as the margin of formal governance.

The case of São Paulo is indicative of urban landscapes produced through uneven processes of consolidation, where efforts to embed necessary infrastructures are complicated by the logistical and financial dynamics of state capacity. In this sense, while being clear about the particularities of São Paulo's urban form, I suggest that insights learned there could speak to other southern cities that combine long histories of informal urbanization, democratic political regimes, and fiscal constraints. Of course, preserving the particularity of Brazil's democracy and history of urbanization is important, and I do not suggest that lessons learned from São Paulo should be uncritically used to intervene into other cities. I do, however, suggest that a comparative approach that draws from southern theory requires us to take seriously the lessons learned from cities like São Paulo in thinking through the global dynamics of contemporary urban governance (Robinson, 2002; Roy, 2007; See too Hart, 2006, 2016). In this sense, I argue that São Paulo’s case could offer lessons for other southern (and northern) cities battling flooding alongside dispossession, while being clear that the form that these interventions will subsequently take will of course depend on local environmental and political dynamics. Breaking the link between social displacement and environmental upgrading requires that we take seriously the intimate, banal ways in which urban landscapes are made and remade by those who inhabit them. 


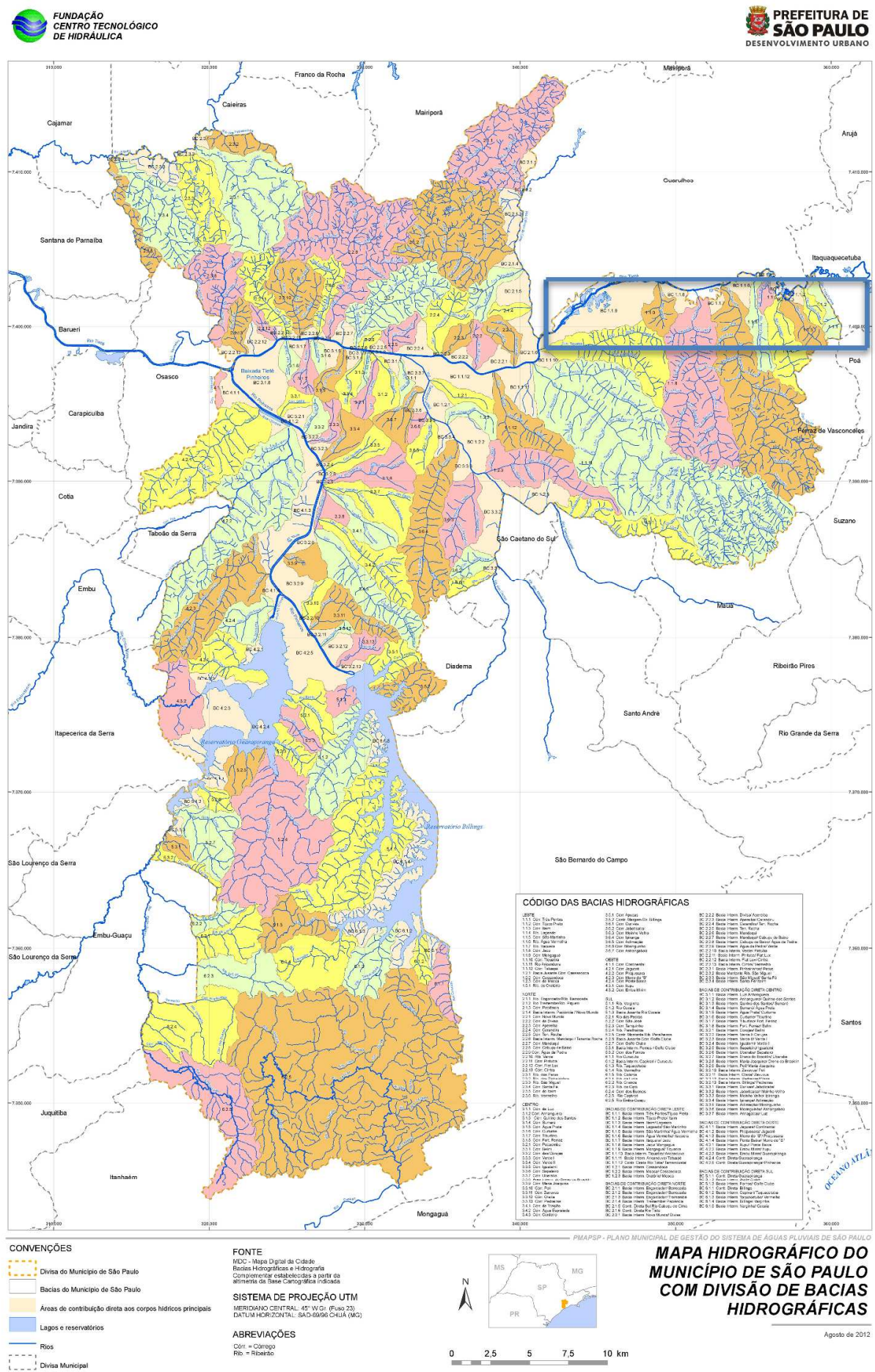

Figure 1: Hydrological Map of the city of Sao Paulo, with approximate area of the várzea highlighted. Produced by the mayor's office of São Paulo and the Fundação Centro Tecnológico De Hidráulica. Available at: http://www.aguaspluviais.inf.br/Mapas/Mapa_hidrografico_com_bacias.pdf 


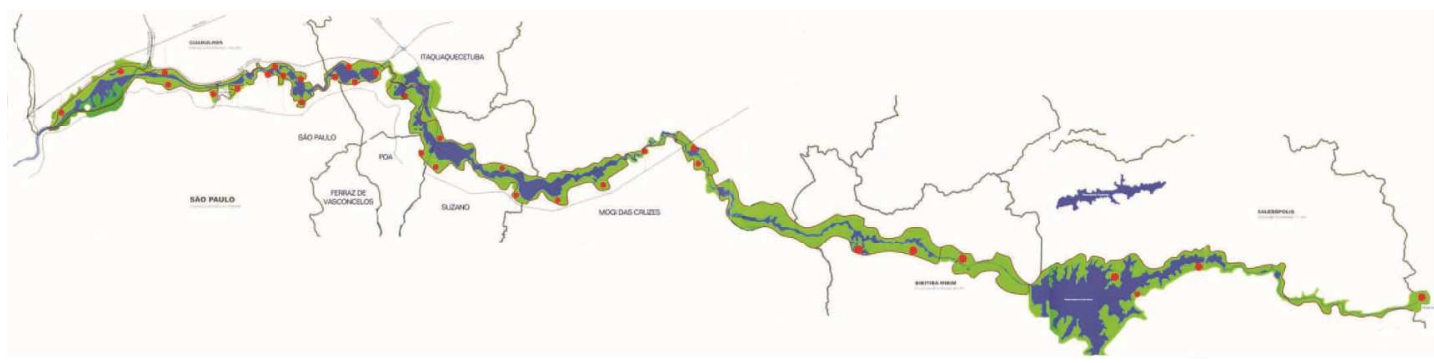

Figure 2: The proposed extent of the Parque Várzeas do Tietê. Available at: http:/ / www.daee.sp.gov.br/index.php?option=com_content\&view=article\&id=370:parquevarzeas-do-tiete-o-maior-parque-linear-do-mundo

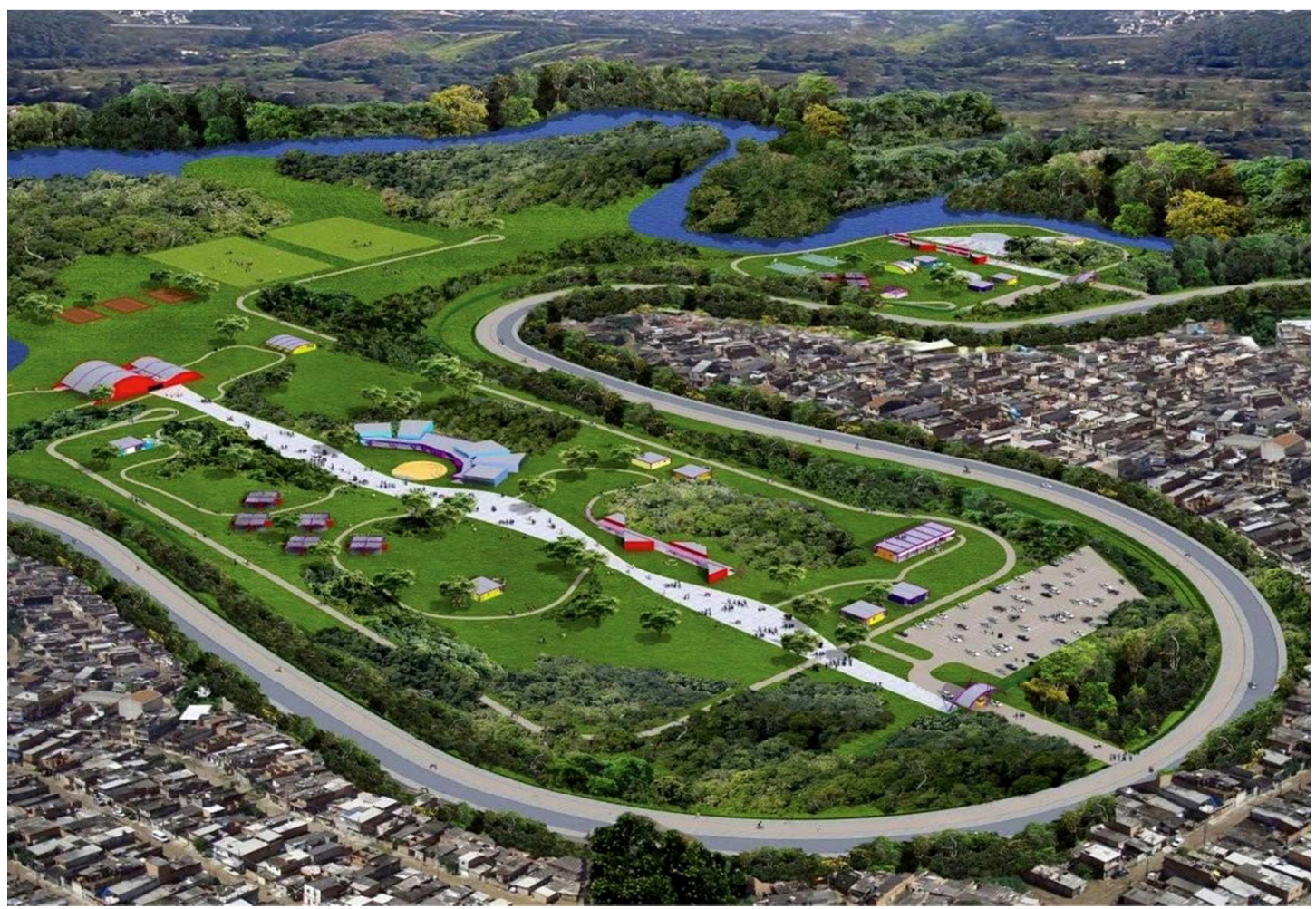

Figure 3: Design for the Parque Várzeas do Tiete. Available at: http:/ / www.daee.sp.gov.br/index.php?option=com_content\&view=article\&id=370:parquevarzeas-do-tiete-o-maior-parque-linear-do-mundo 


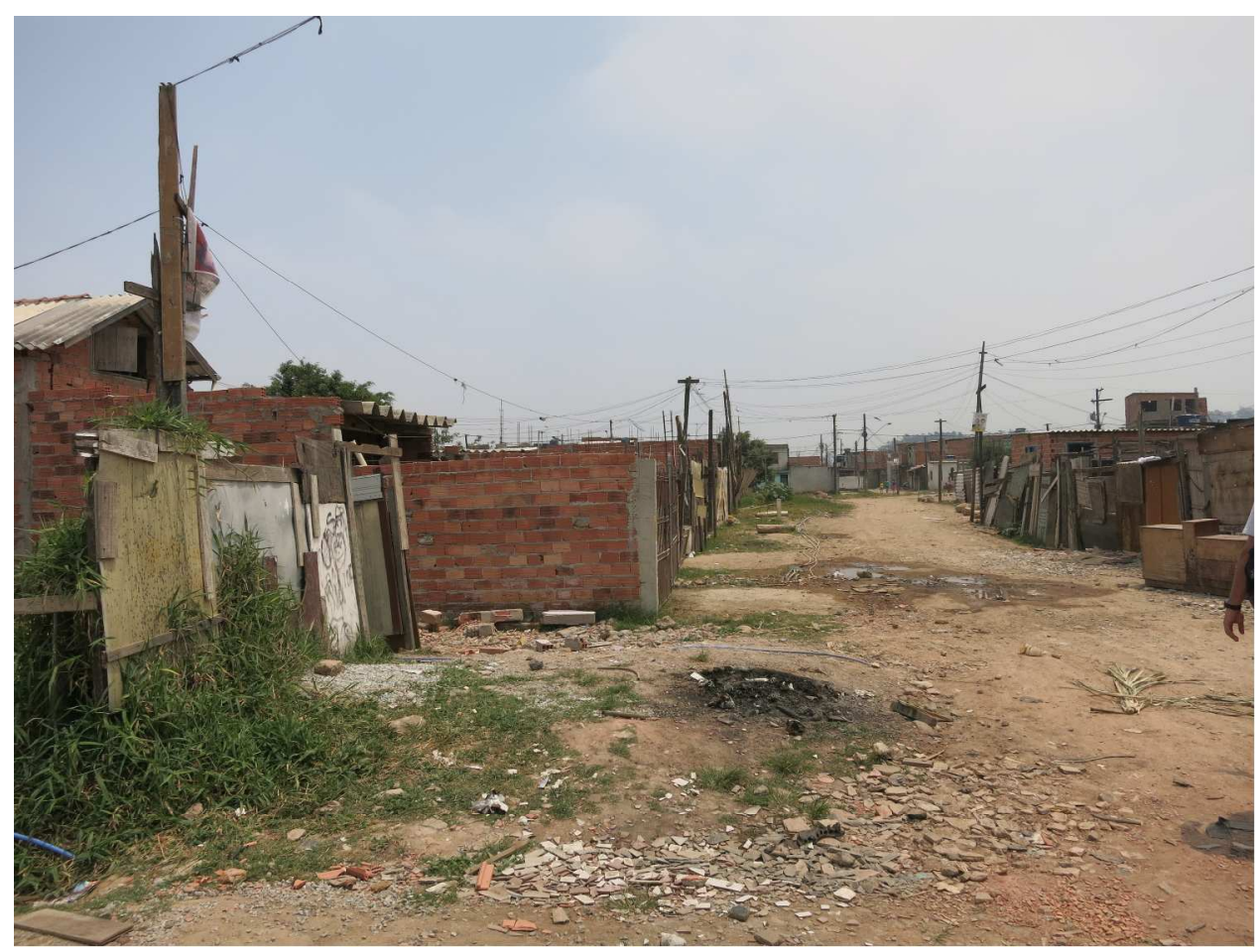

Figure 4: 2014 Construction in Jardim Pantanal, eastern zone of São Paulo. Photo by the author.

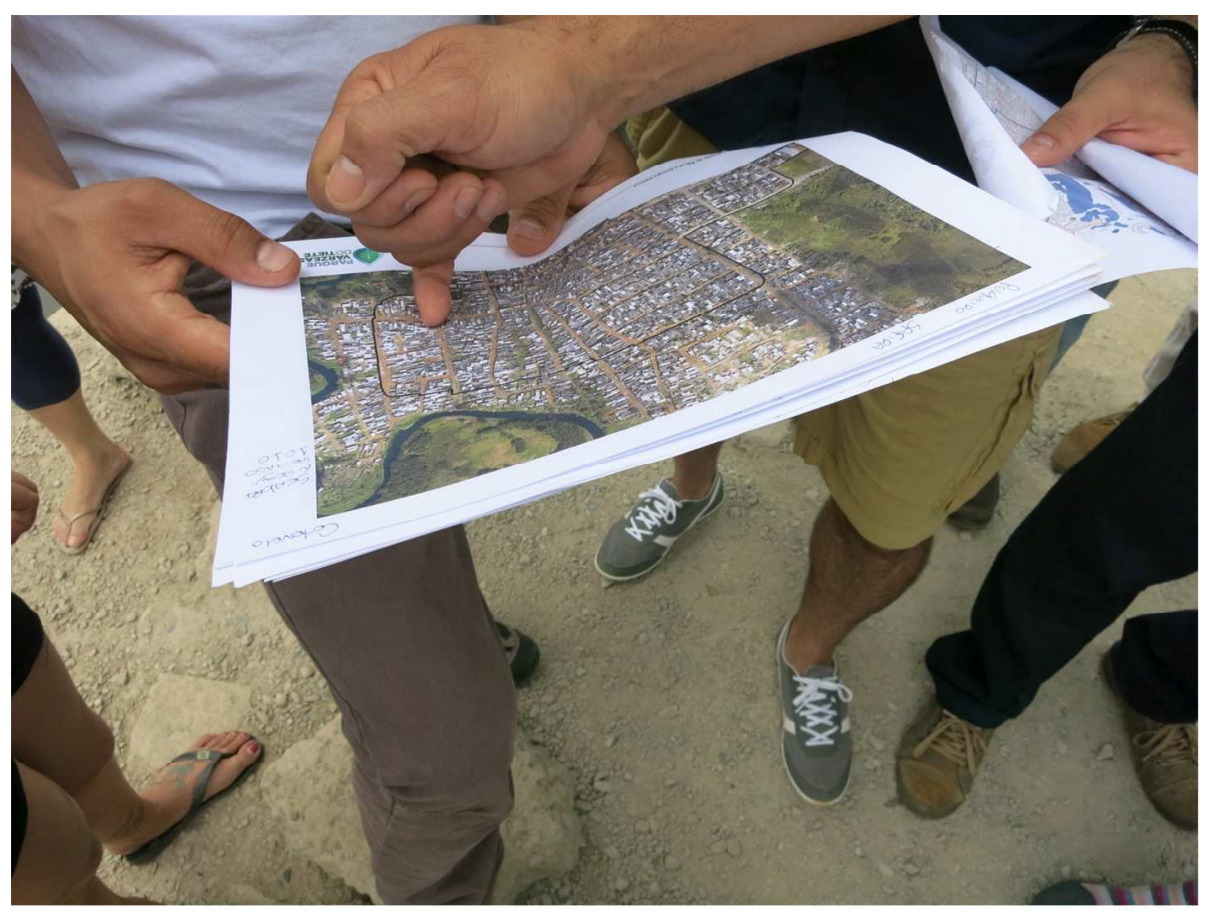

Figure 5: Cartographic Anxiety in Jardim Pantanal, 2014. Photograph by the author. 
Abers R.N. and M.E. Keck (2014) Practical Authority: Agency and Institutional Change in Brazilian $W$ ater Politics. Oxford University Press, Oxford.

Amin, A. (2014) Lively infrastructure. Theory, Culture \& Society 31.7-8, 137-161.

Anand, N. (2017). Hydraulic City: Water and the Infrastructures of Citizenship in Mumbai. Duke University Press.

Angel, J., \& Loftus, A. (2017). With-against-and-beyond the human right to water. Geoforum.

Angel, J. (2017). Towards an Energy Politics In $\square$ Against $\square$ and $\square$ Beyond the State: Berlin's Struggle for Energy Democracy. Antipode, 49(3), 557-576.

Bakker, K. (2010) Privatizing water: governance failure and the world's urban water crisis. Cornell University Press, Ithaca.

Banzhaf, S. and R.P. Walsh (2006) Do People Vote With Their Feet?: An Empirical Test of Environmental Gentrification. Resources for the Future working paper.

Barboza, L. (2015) A Identidade do movimento por urbaniz̧ação e lagalização do pantanal da zona leste - SP: Esperança e desalento na luta contra o deslocamento populacional [The identity of the movement for urbanization and legalization of Pantanal in the Eastern Zone - SP: Hope and discouragement in the fight against displacement]. Scortecci, São Paulo.

Barnes, J. (2016). States of maintenance: Power, politics, and Egypt's irrigation infrastructure. Environment and Planning D: Society and Space, 0263775816655161.

Bhan, G. (2016) In the Public's Interest: Evictions, Citizenship, and Inequality in Contemporary Delhi . University of Georgia Press, Athens.

Boulos, G. (2014) Por que Ocupamos: Uma Introdução à Luta dos Sem-Teto. Scortecci, São Paulo.

Caldeira, T. P. (2001) City of walls: crime, segregation, and citizenship in São Paulo. University of California Press, Berkeley.

Caldeira, T. P. (2016) Peripheral urbanization: Autoconstruction, transversal logics, and politics in cities of the global south. Environment and Planning D: Society and Space.

Canholi, A. (2005) Drenagem urbana e controle de enchentes [Urban Drainage and Flood Control]. Oficina de Textos, São Paulo.

Carse, A. (2012) Nature as infrastructure: Making and managing the Panama Canal watershed. Social Studies of Science 42.4, 539-563. 
Checker, M. (2011) "Wiped out by the "greenwave" : environmental gentrification and the paradoxical politics of urban sustainability." City \& Society 23.2, 210-229.

Cohen, D.A. (2016) The Rationed City: The Politics of Water, Housing, and Land Use in Drought-Parched São Paulo. Public Culture 28(2 79), 261-289.

Coslovsky, S. V. (2015) Beyond Bureaucracy: How Prosecutors and Public Defenders Enforce Urban Planning Laws in São Paulo, Brazil. International Journal of Urban and Regional Research, 39(6), 1103-1119.

de Sant'Anna, D. (2007) Cidade das águas: Usos de rios, córregos, bicas e chararizes em São Paulo (1822-1901) [City of water: Uses of rivers, streams, taps, and fountains in São Paulo (1822-1901). Editora Senac, São Paulo.

Departamento de Águas e Energia Elétrica (2015) Parque Várzeas do Tietê - O Maior Parque Linear do Mundo. [WWW Document]. URL

http:/ / www.daee.sp.gov.br/index.php?option=com_content\&view $=$ article\&id=370:parq

Dooling, S. (2009) Ecological gentrification: A research agenda exploring justice in the city. International Journal of Urban and Regional Research, 33.3, 621-639.

Doshi, S. (2013) The Politics of the Evicted: Redevelopment, Subjectivity, and Difference in Mumbai's Slum Frontier. Antipode, 45, 844-865.

Furlong K (2014) STS beyond the "modern infrastructure ideal": Extending theory by engaging with infrastructure challenges in the South. Technology in Society 38: 139-147.

Gabriel, N. (2014) Urban political ecology: Environmental imaginary, governance, and the non-human. Geography Compass 8.1, 38-48.

Ghertner, D. A. (2015). Why gentrification theory fails in 'much of the world'. City, 19(4), 552-563.

Ghertner, D. A. (2015) Rule by aesthetics: World-class city making in Delhi. Oxford University Press, Oxford.

Governo do Estado de São Paulo (2010) Programa de recuperacção das várzeas da bacia do alto tietê- pvt: plano diretor de reassentamento (minuta 08_04_2010).

Graham, S., \& Marvin, S. (2001). Splintering urbanism: networked infrastructures, technological mobilities and the urban condition. Psychology Press.

Graham, S. and N. Thrift (2007). Out of Order: Understanding Repair and Maintenance. Theory, Culture \& Society 24.3, 1-25.

Harris, L. M. (2017). Political ecologies of the state: Recent interventions and questions going forward. Political Geography, 58, 90-92. 
Hart, G. (2006). Denaturalizing dispossession: Critical ethnography in the age of resurgent imperialism. Antipode, 38(5), 977-1004.

Hart, G. (2016). Relational comparison revisited: Marxist postcolonial geographies in practice. Progress in Human Geography.

Heynen, N. (2013) Urban political ecology I: The urban century. Progress in Human Geography $38.4,598-604$

Holston, J. (1991), Autoconstruction in Working-Class Brazil. Cultural Anthropology, 6: 447465.

Holston, J. (2008) Insurgent citizenship: Disjunctions of democracy and modernity in Brazil. Princeton University Press, Princeton, NJ.

Jacobi, P. R., A.P. Fracalanza and S. Silva-Sánchez (2015). Governança da água e inovação na política de recuperação de recursos hídricos na cidade de São Paulo [Water governance and innovation in the policy of recuperating water resources in the city of São Paulo]. Cadernos Metrópole 17.33, 61-81.

Jorge, J. (2006) Tietê: o rio que a cidade perdeu. São Paulo, 1890-1940 [Tietê: the river that the city lost. São Paulo, 1890-1940]. Alameda/Fapesp, São Paulo.

Júnior, M. L. (2012). Infraestruturas urbanas: uma contribuição ao estudo da drenagem em São Paulo [Urban infrastructures: a contribution to the study of drainage in São Paulo]. Doctoral Dissertation, University of São Paulo, São Paulo.

Júnior, A.S. (2013). "O custo social de algumas obras já ultrapassa o da construção em si." Engenharia 615.

Kaika, M. (2005). City of flows: Modernity, nature, and the city. Routledge, London.

Keck, M. (2002). Water, water, everywhere, nor any drop to drink. In P. Evans (ed.), Livable cities?: urban struggles for livelihood and sustainability, University of California Press, Berkeley.

Koslov, L. (2016). The Case for Retreat. Public Culture, 28(2 79).

Kowarick, L. (2009). Viver em risco. São Paulo, Ed, 34.

Lawhon, M. and A. Makina (forthcoming) Provincializing urban appropriation: Agonistic transgression as a mode of actually existing appropriation in South African cities. Singapore Journal of Tropical Geography.

Lawhon, M., Nilsson, D., Silver, J., Ernstson, H., \& Lwasa, S. (2017). Thinking through heterogeneous infrastructure configurations. Urban Studies. 
Mandelman, A. (2015) Porous Boundaries and Permeable Places: Ordering Nature in the Mississippi River Delta, 1718-2012. Doctoral Dissertation, University of WisconsinMadison, Madison, WI.

Marques, E. (2014) Estrutura Social e Segregação em São Paulo: Transformações na Década de 2000. DADOS - Revista de Ciências Sociais 57(3), 675-710.

Mathur, A. and D. da Cunha (Eds.) (2014). Design in the Terrain of Water. Applied Research+ Design Publishing, San Francisco, CA.

Meyer, H., M. Dale and D. Waggonner (Eds.) (2009) Dutch Dialogues, New

Orleans/Netherlands: Common Challenges in Urbanized Deltas. Sun, Amsterdam.

Milligan, B. (2015) Landscape Migration. Places Journal. [WWW document]. URL https://placesjournal.org/article/landscape-migration/

Nobre, C., I. Martin, and P. Lima (2015) Quota Ambiental: o desafio de ser simples em território complex. Observa SP, October. [WWW Document]. URL

https://observasp.wordpress.com/2015/10/14/quota-ambiental-o-desafio-de-ser-simplesem-territorio-complexo/

Observatório de Remoções (2012) por um observatório das remoções no município de são paulo [WWW Document] Available at: https://www.observatorioderemocoes.fau.usp.br/wpcontent/uploads/2015/06/Observatorio_REMOCOES.pdf

Pacheco, P. (2012) Jardim Romano e Vila Itaim: o drama das enchentes do rio Tietê [Jardim Romano e Vila Itaim: the drama of the Tietê River's floods]. [WWW document]. URL http:/ /www.youtube.com/watch?v=1Ob9gTwOdzs

Pardue, D. (2015). Lessons from São Paulo: A Deserved Shift in Urbanization Policy. The Postcolonialist. [WWW Document] http://postcolonialist.com/civil-discourse/lessons-saopaulo-deser

Pasternak, S. and C. D’Ottaviano (2016) Favelas no Brasil e em São Paulo: avanços nas análises a partir da Leitura Territorial do Censo de 2010. Cad. Metrop. São Paulo 18(35).

Patrick, D. J. (2014) The matter of displacement: a queer urban ecology of New York City's High Line. Social \& Cultural Geography, 15.8, 920-941.

Pereira, D. (2012) Territorialização Da Metrópole Paulista: Ocupação Das Várzeas Do Rio Tietê Em Um Quadro De Diversidade Político-Administrativa [Territorialization of the Paulista metropolis: Occupation of the floodplains of the Tietê river in a political-

administrative diversity framework]. [WWW document]. URL

http://www.ub.edu/geocrit/coloquio2012/actas/07-D-Pereira.pdf

Perry, K. K. Y. (2013) Black Women against the Land Grab. University of Minnesota Press, Minneapolis, MN. 
Pieterse, E. (2013). City futures: Confronting the crisis of urban development. Zed Books, London.

Rademacher, A. (2011) Reigning the River: Urban Ecologies and Political Transformation in Kathmandu. Duke University Press, Durham, NC.

Ranganathan, M. (2014) "Paying for Water, Claiming Citizenship: Political Agency and Water Reforms at the Urban Periphery". International Journal of Urban and Regional Research 38.2, 590-608.

Robinson, J. (2002). Global and world cities: A view from off the map. International Journal of Urban and Regional Research, 26(3), 531-554

Rolnik, R. (1997) A cidade e a lei: legislação, politica urbana e territórios na cidade de São Paulo [The city and the law: Legislation, urban politcy and territories in the city of São Paulo]. Studio Nobel, São Paulo.

Rolnik, R. (2015). Guerra dos lugares: a colonização da terra e da moradia na era das finanças [War of places: The colonization of land and of housing in the era of finances]. Boitempo, São Paulo.

Roy, A. (2005) Urban informality: toward an epistemology of planning. Journal of the American Planning Association, 71(2), 147-158.

Roy, A. (2009) The 21st-century metropolis: new geographies of theory. Regional Studies 43(6), 819-830.

Porto, M. (2012) Gestão de Recursos Hidricos em São Paulo [Water resource management in São Paulo]. In B. Padovano and M. Numar (Eds.) São Paulo: Em Busca da Sustentabilidade [São Paulo: In search of sustainability], Editora Pini Ltda, São Paulo.

Seabra, O. (1987) Os meandros dos rios nos meandros do poder: Tietê e Pinheirosvalorização dos rios e das várzeas na cidade de São Paulo [The meanders of the rivers in the meanders of power: Tietê and Pinheiros-valorization of the rivers and of the floodplains in the city of São Paulo]. São Paulo. Doctoral Dissertation, University of São Paulo, São Paulo.

Silva, R (2012) Águas e Saneamento: Desafios para a Metrópole [Water and sanitation: Challenges for the metropolis]. In B. Padovano and M. Numar (Eds.) São Paulo: Em Busca da Sustentabilidade [São Paulo: In search of sustainability], Editora Pini Ltda, São Paulo.

Silver J (2014) Incremental infrastructures: Material improvisation and social collaboration across post-colonial Accra. Urban Geography 35(6): 788-804.

Soares, M. C. (2014) Parques lineares em São Paulo: uma rede de rios e áreas verdes que conecta lugares e pessoas [Linear parks in São Paulo: A network of rivers and green spaces that connect places and people]. MS dissertation, University of Sao Paulo, São Paulo.

Swyngedouw, E. (2004) Social power and the urbanization of water: flows of power. Oxford University Press, Oxford. 
Swyngedouw, E. and N. Heynen (2003). Urban political ecology, justice and the politics of scale. Antipode 35.5, 898-918.

Thrift, N. (2005) But malice aforethought: cities and the natural history of hatred. Transactions of the Institute of British Geographers 30.2, 133-150.

Truelove, Y. (2011). (Re-) Conceptualizing water inequality in Delhi, India through a feminist political ecology framework. Geoforum 42(2): 143-152.

UGP-Várzeas (2015) relatório semestral de acompanhamento da execução do programa várzeas do tietê - pvt $2^{\circ}$ semestre/2015. [WWW Document]. URL http://www.daee.sp.gov.br/images/documentos/pvt/rs08.pdf

Vasudevan, A. (2014). The makeshift city Towards a global geography of squatting. Progress in Human Geography.

von Schnitzler, A. (2016) Democracy's Infrastructure: Techno-Politics and Protest after Apartheid. Princeton University Press, Princeton, NJ.

Wachsmuth, D., Cohen, D. A., \& Angelo, H. (2016). Expand the frontiers of urban sustainability. Nature 536(7617), 391.

Yiftachel, O. (2009) Theoretical notes on 'gray cities': the coming of urban apartheid? Planning Theory, 8.1, 88-100.

Zeiderman, A. (2016) Endangered City: The Politics of Risk and Security in Bogotá. Duke University Press, Durham. 